\title{
Introduction
}

\section{Teresa Wright}

Chinese citizens are far from docile; they regularly and vociferously rise up in collective protest and engage in resistance. In some cases, they successfully pressure political and economic elites to satisfy their demands, while in others they are brutally suppressed. In most instances, the results are mixed. A glance at the headlines in just the first nine months of 2018 illustrates the wide array of contentious acts that Chinese citizens have felt compelled - and sufficiently empowered - to undertake. In July and August 2018 in the southern city of Shenzhen, the non-profit China Labour Bulletin recorded 279 worker protests, twelve of which involved police intervention. Among these, workers at Jasic Technology launched a push to establish a union branch and were joined by a coalition of students, grassroots Maoist organizations, and retired Communist Party officials. ${ }^{1}$ Meanwhile, truck drivers in at least twelve cities across China participated in a massive strike in which they blocked roads for dozens of miles, demanding lower gas prices, higher pay, and an end to excessive tolls and arbitrary fees and fines. ${ }^{2}$ In March 2018, as the \#MeToo movement spread in China, the online publication Feminist Voices was "permanently suspended" from popular social media platforms. ${ }^{3}$ In September, hundreds of Christian believers flocked to their church in the city of Zhengzhou (in central Henan province) to stop local authorities from confiscating and destroying church items and structures that had been designated as facilities for "illegal" religious gatherings. ${ }^{4}$ The same month, more than 600 citizens in the city of Leiyang (in central Hunan province) gathered outside the local police headquarters to protest the city's plans to deal with public school over-crowding by forcing students into low-quality private schools with relatively high fees. ${ }^{5}$ And through 2017 and 2018, hundreds of thousands of China's ethnic minority Uyghurs have been surveilled and forced into extrajudicial detention camps as part of the government's "Strike Hard Campaign against Violent Extremism."6

These are just a few of the tens of thousands of yearly protests that have emerged in China in recent years. In 2005, the last year that the Chinese government published official statistics on "mass incidents," there were 87,000 such occurrences, as compared with roughly 5,000-10,000 per year in the early 1990s and fewer than 1,000 a year in the 1980s. Since 2005, reliable statistics have been more elusive, but most sources agree that the number of yearly popular protests has remained in the high tens of thousands. In 2010, according to some mainland Chinese scholars, there were as many as $180,000 .^{7}$

Spanning the vast terrain and wide array of demographic groups within the People's Republic of China, this Handbook explores individual and collective acts of protest and resistance that have been undertaken by Chinese citizens since 1989. Bringing together new and original research from top scholars and rising stars based in mainland China, Hong Kong, Australia, Canada, Europe, and the United States, the volume collects some of the best work being done on protest and resistance in China today.

A key contribution of this Handbook is empirical: it provides readers with a rich body of data on protests and acts of resistance, painstakingly collected, insightfully analyzed, 
and clearly presented. Thus, the volume serves those interested in knowing the details of specific types and occurrences of individual and collective contention in Chinaincluding environmental protests, cyber-activism, religious resistance, "rights protection" by lawyers, urban homeowner activism, factory worker strikes, rural opposition to landtakings, and movements calling for greater autonomy and democracy in Hong Kong and among ethnic minority groups.

While illuminating the complexity and diversity of protest and resistance in contemporary China, this Handbook also explores a number of unifying underlying themes. Most generally, the chapters herein examine the ways in which acts of resistance and protest have affected government-society relations in recent years. Included in this inquiry is discussion of how, when, and why individuals and groups have engaged in contentious acts, and how the targets of their complaints have responded. Through this exploration, the chapters shed light on the stability of China's existing political system, and its likely future trajectory.

The Handbook is organized as follows. In Part 1, Andrew Wedeman and Christian Göbel look broadly at protest and resistance in China, providing overviews of recent trends. Wedeman opens the section, examining the puzzling confluence of widespread popular unrest and remarkable regime resilience, and laying out the major types and general progression of protest from the 1990s through the present. The chapter employs the literature on collective contention to question common assertions that pervasive popular protests presage a "coming collapse" of the CCP-dominated regime, demonstrating that such a view does not sufficiently recognize the complicated and contingent nature of popular protest - both in China and elsewhere. In the second chapter in this section, Göbel utilizes a more quantitative approach, drawing on a massive data set of nearly 75,000 protest incidents. Along with tracking the rise, extent, and decline of different kinds of protests by various demographic groups (including migrant workers, middleclass homeowners, and evictees from rural land and urban housing), Göbel examines the factors that influence the likelihood of repression. In addition, he presents data on the nature of protestors' goals. Overall, the chapters in this section show that simple generalizations about popular protest and regime stability do not withstand empirical scrutiny. At the same time, the data examined in this section do not suggest that China's CCP-dominated political system is fundamentally unstable.

In Part 2, Pitman Potter, Eva Pils, Hualing Fu, and Sophia Woodman look at protest and resistance involving China's legal system and other political entities. Potter traces the CCP's use of law to control dissent, protest, and political expression from the early post-Mao era through the present. In recent years, he shows, the regime's formalistic use of the law (claiming to protect political rights and to abide by domestic and international documents on the topic, while ignoring them in substance) has engendered popular expectations that conflict with political authorities' desire to use the law to buttress their authority and legitimacy. Pils drills deeper into this phenomenon with a detailed examination of human rights lawyers that have challenged the regime to follow its own legal commitments. Although such individuals have been subjected to official repression since the time of their emergence in the early post-Mao period, under the administration of current CCP leader Xi Jinping, the disjuncture between the regime's statements and actions has become much starker. At the time of this writing, rights lawyers' use of the law to protect citizen rights has not only been categorized as treasonous, subversive political 
opposition, but also has led to the portrayal of rights defenders as enemies to be crushed. Many key individuals in the Chinese human rights defense movement have suffered arrest, torture, "TV trials," and criminal punishment as a consequence. Also in this section, $\mathrm{Fu}$ examines use of the law by both the regime and citizens, but focuses on collective legal claims - such as class action suits and public interest litigation (PIL) - from the early 1990 s through the present. In contrast to the suppression of rights lawyers, in recent years upwards of 2,000 PIL cases have been filed by government procuratorates in areas of demonstrated public discontent: the natural environment, food and medicine safety, and state-owned land and assets. This represents an attempt by CCP elites to address popular concerns in a manner that ensures regime control over the process and outcome. However, as $\mathrm{Fu}$ emphasizes, the potential for PIL to successfully ameliorate public dissatisfaction is severely circumscribed by current constraints on activist lawyers and public interest nongovernmental organizations (NGOs). The final chapter in this section, by Woodman, focuses on local-level interactions between citizens and governmental authorities, looking at specific instances wherein citizens have voiced complaints and requests to urban resident and villager committees, and tracing iterative processes of officials' responses and citizens' counter-responses. Together, these chapters illustrate the complexity of interactions and outcomes that have arisen when citizens engage the courts and other official entities in pursuit of redress or support. Although in some respects the regime has appeared to almost entirely disregard its own laws, in other respects the courts and local political bodies have been responding positively to expressed public concerns.

Part 3 examines the experiences and acts of resistance undertaken by rank-and-file urban workers. The first chapter in the section, by Jenny Chan and Mark Selden, examines the development of labor law from the early 1990s through the present, tracing both how this evolution has been a reaction to worker protest, and how workers have used the law to engage in activism to protect their rights and interests. Overall, they show that CCP authorities have evidenced a clear desire to improve worker-employer relations, with the goal of ensuring social stability. Official encouragement of labor mediation and arbitration is a prime case in point. The results have been mixed; the basic rights of certain categories of workers have been strengthened, yet earlier protections of state sector workers have been diminished and the use of temporary and contract "dispatch laborers" lacking legal protection has increased.

Next, Lu Zhang provides an overview of trends and developments in worker resistance and government responses, with a particular focus on 2010 through the present. She finds that over time, workers across many categories have become more prone to engage in protest activities, with increased organization and unity (in part due to the use of social media), and more varied demands. In turn, amidst various accommodative and repressive reactions, government authorities have pressured the official trade union (the All China Federation of Trade Unions, ACTFU) to become more representative of worker interests.

The chapters in this section by Manfred Elfstrom and Darcy Pan look at how these broad developments have played out in two detailed case studies, both of which underscore the uncertain, precarious context experienced by China's rank-and-file workers. Looking at taxi drivers during the first two decades of the new millennium, Elfstrom examines their working conditions, complaints, and acts of resistance, including the specific tactics that they have employed. In so doing, he assesses the factors that influence employer and government responses to taxi driver protests. He finds that while many such actions have 
been successful in eliciting at least partial concessions, they also have involved repressive government actions. Moreover, Elfstrom shows that these dynamics have come to be seen as "normal" by the drivers, their employers, and local authorities. As such, they have been able to ameliorate taxi drivers' complaints while simultaneously containing them within the existing CCP-controlled political structure.

In the final chapter in this section, Pan examines grassroots labor NGOs in South China, with a particular focus on the harassment and suppression of some such organizations beginning in 2012. Drawing on interviews and participant observation, Pan shows how the unpredictable political environment experienced by labor NGOs has engendered guarded behavior, speculation and rumor, and self-censorship among their leaders. Overall, the chapters in this section underscore the importance of recognizing the agency and potential for protest success of rank-and-file workers-even those in precarious employment circumstances within an authoritarian state. As pointed out most explicitly by Elfstrom, studying how this can occur may provide lessons for the many workers around the world who have been experiencing increasing precariousness in their employment conditions.

In Part 4, Lei Guang and Yang Su, and Christopher Heurlin focus on rural protest and resistance. Guang and Su examine the evolution of China's petition system, which typically is the first stop for aggrieved citizens. Next, they scrutinize over 1,200 collective petitions submitted in a largely rural province in 2002-2003, elucidating the nature of petitioners' demands and showing how their social status, tactics, and numbers may affect their access to officials, but not necessarily their likelihood of success in resolving their grievances. Reaching a conclusion that coincides with many other chapters in this volume, they argue that the petition system both enables and constrains citizen mobilization. The second chapter in this section, by Heurlin, examines the massive wave of landrelated protests that arose in relatively wealthy rural areas of Zhejiang province during the first decade of the 2000s. Drawing on archival material from Chinese government sources and interviews conducted in 2009-2010, Heurlin shows how sudden changes in perceived land values and local injustices explain the geographic distribution of this protest wave. He finds that Zhejiang authorities responded quite favorably to the protests, largely addressing the farmers' demands. The reasons for this, Heurlin argues, were: (i) that the scale of the unrest attracted the attention of central CCP authorities, and (ii) that Zhejiang province had the financial wherewithal to make material concessions. As with the chapter by Elfstrom, Heurlin's study indicates the circumstances under which even resource-poor and relatively low-status groups in China can successfully engage in protest.

Part 5 turns to protests by relatively well-off Chinese citizens: urban middle-class homeowners. In comparison to other demographic groups, this group has been the most successful in achieving their goals via protest. At the same time, there are important qualifications to their success. The first chapter in this section, by Zhiming Sheng, draws on domestic media coverage, personal interviews, and participant observation to examine nearly 200 cases of homeowner resistance over roughly 13 years-laying out the factors that correlate with homeowner protest success. Sheng finds that in civil disputes, homeowners are successful roughly half the time, but when government agencies are implicated in the homeowners' complaints, their success rate drops to about one-third. Looking at participant mobilization, he finds that when half or more of all homeowners 
in a community join a protest action, they are highly likely to achieve their goals. More generally, protests involving 50 or more homeowners have a greater chance of succeeding than do those with fewer than 50, but the likelihood of success does not continue to rise as numbers further exceed 50. Further, Sheng shows that when homeowners engage in non-institutionalized radical actions, they are less likely to succeed.

The second chapter in this section, by Dragan Pavlićević, Long Sun, and Zhengxu Wang, underscores this finding via a somewhat different focus: the emergence of and activities undertaken by cross-community homeowner organizations, especially in Beijing. Based on interviews with homeowners and homeowner leaders, participant observation, and homeowners' internal documents spanning 2006-2017, the authors detail how homeowners have capitalized on legal and institutionalized frameworks, strategically avoiding conflict with political authorities and acting within the "boundaries of permissible and desirable participation in local politics." In doing so, Pavlićević et al. document concrete successes, including changes in government policy and behavior. At the same time, they emphasize that homeowner organizations remain politically vulnerable, and that their gains have come only through stressing their conformance with the state's desire to maintain "social harmony."

Some of the same features are evident in environmental protests, the subject of Part 6. The four chapters in this section-by H. Christoph Steinhardt, Björn Alpermann and Maria Bondes, Natalie Wong, and Simona Grano and Yuheng Zhang-examine recent trends and developments in this category of protest, finding that those undertaken primarily by well-to-do urbanites have been quite successful. At the same time, these chapters highlight the boundaries within which even successful contention has occurred, and note that China is still quite far from having anything resembling a developed "environmental movement." Examining more than two dozen major cases of environmental contention between 2007 and 2016, Steinhardt argues that the notion of an "environmental public interest campaign" best characterizes a majority of these events. Unlike "NIMBY" demonstrations, activists in these cases pressed for policy changes related to collective goods and large and diverse groups of people. They also were critical of China's policymaking process, and framed their demands in affection for their collectively owned local homeland. At the same time, these protests lacked ideological and organizational coherence, such that they cannot be categorized as an emergent "environmental movement." Alpermann and Bondes take a somewhat more focused approach, looking at nine cases of environmental activism against waste incineration facilities. They demonstrate that - at least through 2014 - national experts, lawyers, and NGOs played crucial roles in the spread and success of these citizen efforts, resulting in a pattern of "networked contention" that has been quite successful even within the limits of the CCP-controlled political system. More recent moves by Xi Jinping to repress rights lawyers and constrict the operation of NGOs are likely to undermine these gains.

The other two chapters in this section, by Wong, and Grano and Zhang, analyze more specific cases of successful environmental protests. Looking in detail at citizen opposition to the construction of a waste incinerator in the Panyu district of Guangzhou beginning in 2009, Wong shows how activists effectively pressed the Guangzhou city government to abandon the project. Even more, she finds that the protests resulted in the establishment of institutionalized mechanisms for citizens to participate in decision-making about city waste management, and the creation of a "green" civic group that promotes waste sorting 


\section{Handbook of protest and resistance in China}

in the city. Perhaps the most hopeful story found in this volume, it allows us to assess the factors that contribute to positive developments in state-society relations within China's current political environment. The chapter by Grano and Zhang is also optimistic, though more boundedly so. Providing one of the first scholarly examinations of anti-nuclear activism in China, the chapter focuses in particular on opposition to a nuclear facility in the northeastern city of Lianyungang in 2016. Based on interviews with participants in the protests, the chapter shows how international and domestic events - such as the Fukushima nuclear disaster in 2011 and anti-waste incinerator protests in mainland China - influenced both citizens and local authorities, and led to the abandonment of the project in that locality. At the same time, Grano and Zhang emphasize that, as has been the case in anti-incinerator protests, the project is likely to be moved to a location where residents are less likely to protest - typically more rural and poor areas where citizens have fewer resources and options. Overall, the chapters in this section highlight the different experiences of groups occupying higher and lower positions within China's polarized socioeconomic structure.

Part 7 looks at a quite different type of resistance in late post-Mao China - that which revolves around religion. This topic also relates to Part 10, on ethnic minority resistance and unrest, but differs in that it does not have a clear ethnic component.

The chapters by Susan McCarthy and Marie-Eve Reny both examine subtle but real forms of resistance-highlighting how citizens often defy regime authorities in a manner that is neither public nor disruptive. They also highlight the wide variation in relations between religious groups and the Party-state. Focusing on underground Catholics and unregistered Protestant churches, Reny argues that informality is a form of defiance - that of central government regulations on the co-optation of religious organizations. Underground Catholic and unregistered Protestant churches have defied such regulations for different reasons. Informality has had mixed socioeconomic and political implications for both, but unregistered Protestant churches are less coerced than underground Catholics. Turning to the work of religious charities (including those that are Buddhist, Muslim, Catholic, and Evangelical Protestant), McCarthy also reveals variation and nuance in their relations with political authorities. She finds that even though those engaged in religious charity generally see their work in patriotic terms, they also can "repurpose" their charity work in a form of non-confrontational resistance against political restrictions. Perhaps most interestingly, McCarthy shows how such actions "can enable relatively marginal social actors to alter the behavior and attitudes of government officials and agencies."

Carsten Vala's chapter, which examines official Christian groups' open resistance to the CCP's anti-cross campaign in 2014-2016, provides further illustration of the wide variation in the forms of resistance undertaken by religious adherents in contemporary China. At the same time, Vala documents the "growing assertiveness and organizational capacity" of some Christian believers, including their pursuit of linkages with other citizens (both locally and nationally) as well as foreign groups. At present, regime authorities have not responded favorably to these developments; to the contrary, they have increased their efforts to restrict and repress this kind of open resistance.

Part 8 turns to another form of resistance and protest that has ranged from open to ambiguous, and that has elicited varied Party-state responses: information and communications technology (ICT)-based resistance and opposition, including blogs and 
mass online "incidents." Jun Liu's chapter links with those in Part 6 in that is examines anti-petrochemical protests. Its focus, though, is on the use of ICTs. Examining collective actions in six cities from 2007 to 2014, Liu shows how digital media have allowed the storage and retrieval of protest information after a protest event, even when political leaders try to eradicate all related information online. Importantly, this has made it possible for citizens to find out about and imitate previous events. However, Liu cautions that under $\mathrm{Xi}$ Jinping, regime authorities have stepped up efforts to censor such information, and have been increasingly successful in doing so. Liu notes that this has been true even though protesters against PX (the petrochemical feedstock para-xylene) have not challenged CCP rule.

The chapters in this section by Rongbin Han and Christopher Cairns illustrate how online activism can both support and challenge Party-state aims. Looking at the 2016 "Diba Expedition" wherein Chinese citizens inundated the Facebook page of Taiwan's president in defense of the "One China" principle, Han illustrates how "nationalistic netizens" simultaneously support the Chinese state and collectively mobilize in ways that political authorities find threatening. The Diba Expedition occurred even though Facebook is banned in China, and despite CCP authorities' efforts to censor threads with mobilizing potential. Nonetheless, most Diba activists did not seem to feel that China's authoritarian system conflicted with their patriotism. At the same time, participants in the Diba Expedition were exposed to new ideas, as liberal activists repeatedly posted entries with links to dissident websites.

Cairns analyzes online discussion surrounding the 2012 downfall of former CCP Politburo member and Chongqing Party Secretary Bo Xilai. He finds that although Party authorities actively censored posts that questioned CCP legitimacy, they allowed criticism directed solely at Bo, including that which involved more general discussions of political corruption in China. Cairns argues that the latter is particularly noteworthy given that these online debates coincided with a sensitive leadership transition (ultimately concluding in the ascension of $\mathrm{Xi}$ Jinping to the top CCP post). Noting that official tolerance of such posts parallels other cases where regime leaders have allowed relative information openness, such as nationalist and environmental online activism, Cairns concludes that in this respect CCP elites may appear responsive to the online public's demands even under conditions of harsh digital repression.

In Parts 9 and 10, we turn to protests originating in China's "Special" and "Autonomous" regions_-including Hong Kong, Xinjiang, and Inner Mongolia. In Hong Kong and Xinjiang, in recent years collective contention has overtly challenged the legitimacy of CCP rule. However, the actions of protestors and regime authorities have been quite different in Hong Kong and Xinjiang, with the former being fundamentally peaceful and the latter involving no small amount of violence. The chapters herein illustrate how different political contexts shape the character of collective contention.

The two chapters in Part 9 focus on Hong Kong. Suzanne Pepper traces the evolution of popular protest in Hong Kong from the 1980s through 2018. During this period, the political context in Hong Kong shifted dramatically-from British rule to CCP rule, and with varying degrees of liberal democratic and authoritarian features over the course of each period. Political contention has centered on the "Basic Law" that has governed Hong Kong since its reunification with mainland China as a "Special Autonomous Region' of the PRC - an arrangement knows as "one country, two 
systems." Pepper details the increasing tension and conflict between Hong Kong protestors and pro-Beijing authorities over time. She argues that this development reflects the growing realization that Hong Kong residents and PRC leaders have had very different understandings of the Basic Law and Hong Kong's political status - especially under Xi Jinping. Simply put, Hong Kongers want genuine political autonomy and basic liberal democratic rights, while PRC authorities believe that Hong Kong is an appendage of the PRC that must be firmly under CCP control. Joyce Nip's chapter focuses more specifically on developments in Hong Kong since the territory's 1997 handover to the PRC, looking in particular at the ways in which independent media have served as "voices of dissent." Examining mass media and social media content, and drawing on Chinese and English journalistic and academic studies, Nip analyzes the spectrum of political positions represented in Hong Kong's independent media, as well as their impact on political developments on the ground. In doing so, she lays out the actions of an "oppositional public sphere" in which dissenting media provide information and arguments that contravene those of Hong Kong's pro-Beijing political establishment. Overall, these chapters show how the unique status of Hong Kong has enabled a far greater degree of overt political opposition and dissent than has been the case in the mainland PRC.

The final section of this volume-Part 10-highlights the complexity of activism on the part of China's ethnic minority groups, as well as varied governmental responses to it. Uchralt Otede examines protests undertaken by ethnic Mongolians in China's "Inner Mongolia Autonomous Region." In response to the destruction of grasslands by the influx of polluting industries into the region, which have brought serious harm to the health and livestock of Inner Mongolian herders in the region, ethnic Mongolians in the area have engaged in a range of collective protests - some of which have entailed violence and casualties. As Otede shows, these protests have been supported by not only herders but also by intellectuals, students, and lawyers across China. Engaging the scholarly literature on "self-relief" and "rightful resistance" - and also making comparisons with protests in Taiwan, Japan, and Han Chinese-dominant areas of the PRC - Otede argues that these protest actions in Inner Mongolia are best categorized as environmental struggles rather than as ethnic conflict.

The chapter by Tom Cliff in this section underscores how notions of ethnic conflict can be used to undermine the legitimacy of activism - highlighting how CCP authorities' relatively sympathetic response to protests in Inner Mongolia reflect their view that these actions have not been fundamentally ethnic in nature. Cliff makes the case that CCP leaders' harsh response to protests and resistance by ethnic minority "others" derives from leaders' fear of unrest on the part of Han Chinese. Further, he argues that Chinese authorities have used the "threat" of ethnic minority unrest to justify Party-state controls over the Han population - what he refers to as the "securitization" of the Chinese populace.

Closing the volume, Justin V. Hastings focuses on acts of contention by Uyghur groups - which, unlike the other protests examined in this Handbook, have been characterized by violence and international connections. Hastings shows that in recent years, a combination of increased domestic repression by $\mathrm{CCP}$ authorities and heightened recruitment efforts by transnational Islamist terrorist groups have led to changes in Uyghurrelated unrest. Along with an uptick in "creative" protests and attacks requiring minimal 
planning and logistics - and targeting Han Chinese civilians and government personnel both inside and outside China's "Xinjiang Uyghur Autonomous Region"-many Uyghur activists shifted away from their earlier focus on achieving separation from the PRC, instead leaving China to join international Islamist terrorist groups.

\section{CONCLUSION}

If there is one overarching conclusion that can be reached from reading the chapters herein, it is that Chinese citizens regularly engage in acts of protest and resistance. At the same time, their actions - and official responses to them-are so varied that they defy sweeping generalizations. This also means that it is impossible to assert that popular resistance in China either supports or undermines CCP rule. In reality, it does both. When citizens are able to use the law, legal mechanisms, and official political institutions to resolve their grievances, CCP legitimacy is buttressed. When these venues fail, skepticism and cynicism with the political system grow.

The chapters in this Handbook also underscore the increasingly divided nature of Chinese society. ${ }^{8}$ In general, groups with higher socioeconomic status have encountered greater success. Perhaps most notably, the chapter by Pavlićević et al. shows how well-off urban homeowner activists have been able to help craft new laws related to their interests. Groups that face lower status and higher marginalization have achieved fewer gains, and often have been subjected to violent treatment by political authorities. Rural residents fall into this category, as do Uyghurs. At the same time, even poor and marginalized groups (such as taxi drivers and migrant workers) have at times been able to successfully press political elites to attend to their demands.

Since the ascension of Xi Jinping to the Chinese Party-state's top posts, CCP authorities have heightened their efforts to constrict popular expression via social media and on the Internet, and have evidenced less tolerance for popular protest and resistance. The mass arrests and harsh punishment of China's "human rights" lawyers is the most glaring example. At the same time, the chapters herein show that even in the Xi Jinping era, Chinese citizens have continued to actively resist policies and practices with which they disagree, and in many cases regime officials have been responsive to public concerns. Although $\mathrm{Xi}$ and other political leaders may feel threatened when citizens engage in protest and resistance, the chapters in this volume suggest that if $\mathrm{CCP}$ elites wish to remain in power and strengthen their legitimacy, their best course of action is to allow citizens to express their grievances and to make the resolution of those complaints governing authorities' top concern.

\section{NOTES}

1. China Labour Bulletin, "Police raid student group as support for Shenzhen Jasic workers grows," 24 August 2018, https://www.clb.org.hk/content/police-raid-student-group-support-shenzhen-jasic-workersgrows; China Labour Bulletin, "Jasic not an isolated case: rare spike in arrests and violent police intervention to dissolve worker protests across China," 3 September 2018, https://www.clb.org.hk/content/ jasic-not-isolated-case-rare-spike-arrests-and-violent-police-intervention-dissolve-worker.

2. They also opposed monopolistic practices in the industry. Tan Jiangying, "Truckers on Strike and the 


\section{Handbook of protest and resistance in China}

Structural Contradictions of China's Logistics Industry," China Change, 15 June 2018, https://chinachange. org/2018/06/15/truckers-on-strike-and-the-structural-contradictions-of-chinas-logistics-industry/.

3. Yaqiu Wang, "Is \#MeToo Changing China?” Washington Post, 17 September 2018, https://www.washing tonpost.com/news/global-opinions/wp/2018/09/17/is-metoo-changing-china/.

4. David Cowhig, "Christian Church Standoff in Zhengzhou, China," David Cowhig's Translation Blog, 10 September 2018, https://gaodawei.wordpress.com/2018/09/10/christian-church-standoff-in-zhengzhou-china/.

5. Josh Chin, "China Protest Over Cash-Strapped City's School Plan Turns Violent," Wall Street Journal, 7 September 2018, https:/www.wsj.com/articles/china-protest-over-cash-strapped-citys-school-plan-turnsviolent-1535886485.

6. Human Rights Watch, "China: Massive Crackdown in Muslim Region," 9 September 2018, https://www. hrw.org/news/2018/09/09/china-massive-crackdown-muslim-region.

7. Sun Liping, "China's Challenge: Social Disorder," Economic Observer 508 (28 February 2011): 10-11, http:// www.eeo.com.cn/ens/feature/2011/05/09/200868.shtml.

8. For an excellent investigation of this phenomenon in urban China, see Dorothy Solinger, ed., Polarized Cities: Portraits of the Rich and Poor in Urban China (New York: Rowman and Littlefield, 2018). 